\title{
Biodecolorization of Anthraquinone and Azo Dyes by Newly Isolated Indonesian White-Rot Fungi
}

\author{
Kharisma Panji Ramadhan", Sita Heris Anita, Maulida Oktaviani, Raden Permana Budi \\ Laksana, Fahriya Puspita Sari, Oktan Dwi Nurhayat, Dede Heri Yuli Yanto*
}

\author{
Research Center for Biomaterials, Indonesian Institute of Sciences (LIPI), Indonesia \\ *Corresponding Author: krs.panji@gmail.com; dede@biomaterial.lipi.go.id
}

Submitted: 2020-09-11. Revised: 2020-11-13. Accepted: 2021-03-02

\begin{abstract}
Water pollution by dyes represents from dyestuff industry becomes an environmental concern. Finding new isolates capable of decolorizing these dyes is important. The study aimed to assess the new isolates of white-rot fungi (WRF) as decolorizing agent of anthraquinone and azo dyes. Decolorization assay were conducted in agar plates and liquid medium. During the decolorization, laccase activities produced by the fungal strains were analyzed. Identification of the fungal strains were investigated using molecular DNA analysis. The results showed that isolates M3, H18, and GP1 were able to decolorize anthraquinone and azo dyes in agar and liquid medium. Based on DNA analysis, isolates M3, H18, and GP1 have the similarity to Trametes sanguinea, Trametes polyzona, and Neofomitella guangxiensis, respectively. Among the fungi, T. polyzona H18 exhibited high decolorization ability (70-90\%) to the dyes $(100 \mathrm{mg} / \mathrm{L})$ after $96 \mathrm{~h}$ incubation. Laccase activity was fluctuated during the reactions with tendency to increase at the beginning until its peak, then decreased at the end of incubation. This study demonstrated the potential of the new isolates from Indonesia to decolorize anthraquinone and azo dyes. The results of the study can provide an alternative for bioremediation agents of contaminated water by synthetic dyes.
\end{abstract}

Key words: decolorization; laccase; textile wastewater; Trametes polyzona; white-rot fungi

How to Cite: Ramadhan, K. P., Anita, S. H., Oktaviani, M., Sari, F. P., Laksana, R. P. B., Nurhayat, O. D., \& Yanto, D. H. Y. (2021). Biodecolorization of Anthraquinone and Azo Dyes by Newly Isolated Indonesian White-Rot Fungi. Biosaintifika: Journal of Biology \& Biology Education, 13(1), 16-25.

DOI: http://dx.doi.org/10.15294/biosaintifika.v13i1.26148

\section{INTRODUCTION}

Synthetic dyes in wastewater discharged by textile industry becomes one of the pollution issues in several decades (Antošová et. al., 2018; Kant, 2012). Dyeing process requires a lot quantity of water (varies from 30 - 50 liters per $\mathrm{kg}$ of cloth) then generating remained colored effluents (Kant, 2012). Estimation of dyes lost in effluents during the process is approximately reaching 10-15\% (Levin et. al., 2010). Effluents release into natural waters will threat the environment (Lavanya et. al., 2016). They are also toxic for flora, fauna, and human. Furthermore, degradation of the dyes led to the depletion of dissolved oxygen levels in water affecting aquatic organisms (Madhushika et. al., 2020).

Commonly synthetic dyes found in textile wastewater are belong to anthraquinone and azo group, which highly resistant to degradation due to their complex and stable structure (Li et al., 2019). The anthraquinone group contains complex aromatic molecular structures, thus resist degradation as well as color-losing in the environment (Šekuljica et al., 2015). Azo dyes, on the other hand, contain one or more azo bonds $(-\mathrm{N}=\mathrm{N}-)$. They are highly toxic against human beings and environment, since its breaking down steps would generate at least 20 carcinogenic aromatics amines without appropriate treatment (Cao et. al., 2018).

Various effluent treatment methods such as adsorption, photolysis, chemical precipitation, electrochemical treatment, coagulation/flocculation, and reverse osmosis have been tried to treat colored effluent (Šekuljica et al., 2015; Padmapriya et. al., 2016). The use of physical and chemical techniques has some consequences e.g. producing a lot amount of sludge where may cause to secondary pollution issue, incomplete color removal, and requiring a huge quantity of chemicals as well as energy which leading to higher running cost (Bibi et al., 2019).

Bioremediation technique becomes a promising strategy to solve this water pollution (Bibi et al., 2019). This biological method is environmentally friendly and offers less sludge by-product compared to physical and chemical system, and relatively lower running cost (Solís et. al., 2012).

In recent years, the researches of white-rot fungi as bioremediation agent have been significantly escalated due to reports that some strains produce extracellular enzymes that capable of degrading dyes wastewater (Šekuljica et al., 2015). One important extracellular enzyme that mainly found abundantly in white-rot fungi and reported play a role in dye decolorization is laccase enzymes (Patel et al., 2014). 
Finding new isolates of white-rot fungi that capable of decolorizing anthraquinone and azo dyes is challenging. Therefore, this study aims to identify three fungal strains newly isolated from Batam and Kuningan Botanical Garden and evaluate their potential as bioremediation agent for anthraquinone (Remazol Brilliant Blue R and Acid Blue 129), mono-azo (Acid Orange 7) and di-azo (Reactive Black 5) dye. Activity of laccase enzyme was investigated during the decolorization assay. The potential fungi could be used as a source for further study to design textile dye wastewater treatment by using bioremediation agent.

\section{METHODS}

\section{Fungal strains}

The newly isolated Indonesian tropical fungi in this research were coded as M3, H18, and GP1. Isolate M3 and H18 were isolated from Batam Botanical Garden, Batam Island while isolate GP1 was obtained from Kuningan Botanical Garden, West Java. They were selected among screened fungal samples collected from above spots. The screening was based on the ability to decolorize anthraquinone dyes (RBBR and AB129) in agar medium. Dyes decolorization and laccase assay in this study were performed in Laboratory of Biomass Conversion Technology \& Bioremediation and Laboratory of Microbiology, Research Center for Biomaterials, Indonesian Institute of Sciences (LIPI).

\section{Dyes decolorization in agar medium}

The fungal isolates were inoculated individually onto Malt Extract Agar (MEA) and incubated at room temperature $\left(25-30{ }^{\circ} \mathrm{C}\right)$ for 7 days. One plug of isolate $(0.5 \mathrm{~cm}$ diameter $)$ was placed onto double layer agar medium and incubated at room temperature $\left(25-30{ }^{\circ} \mathrm{C}\right)$ within 7 days. The double layer agar medium (per liter) was containing of bottom layer: $35 \mathrm{~g}$ Czapek-Dox modified broth, $1 \mathrm{~g}$ $\mathrm{KH}_{2} \mathrm{PO}_{4}, 2 \mathrm{~g}$ yeast extract, $2 \mathrm{~g}$ peptone, $20 \mathrm{~g}$ agar, $2 \mathrm{~g}$ lignin, and $10 \mathrm{~g}$ glucose. The top layer composed of 5 g Malt extract, $10 \mathrm{mg}$ benomyl, $1 \mathrm{~g}$ RBBR/AB129, and $10 \mathrm{~g}$ agar. The $\mathrm{pH}$ was adjusted to 4.5 and autoclaved for 15 minutes at $121^{\circ} \mathrm{C}$ prior to use. Decolorization rates were determined by development of clear zones on agar medium during $96 \mathrm{~h}$ incubation.

\section{Molecular identification analysis}

Molecular identification was carried out using DNA analysis. Isolates were cultured in Potato Dextrose Broth (PDB) for $72 \mathrm{~h}$. The mycelia were harvested and proceed to DNA extraction using Nucleon PhytoPure (GE Life Science) reagent according to the protocol's instruction. Amplification of 5.8S rDNA was performed. Primer ITS4: 5'--TCC TCC GCT TAT TGA TAT GC-- 3'and ITS5: 5'-GGA AGT AAA AGT CGT AAC AAG G--3'were used to amplify the 5.8S rDNA gene from genomic DNA (Cui et al., 2019).

Confirmed PCR products were then sequenced by ABI PRISM 3130 Genetic Analyzer and compared to database with National Center for Biotechnology Information (NCBI)-BLAST. The phylogenic tree was constructed with maximum likelihood (ML) method using MEGA 7 software. The Bootstraps 1000 replication (BS) was used to test the Strength of the internal branches of the phylogenetic trees. The phylogenetic tree of the selected isolates is shown in Figure 2.

\section{Dyes decolorization in liquid medium}

Fungal isolate with each diameter of $0.5 \mathrm{~cm} \mathrm{(3}$ plugs) were added into a $100-\mathrm{mL}$ Erlenmeyer flask consisting $20 \mathrm{~mL}$ of autoclaved Malt Extract Glucose Peptone (MGP) liquid medium. The culture was then placed in a static incubation at room temperature $( \pm$ $25-{ }^{\circ} \mathrm{C}$ ) for 7 days. Per liter MGP broth was consisted of $20 \mathrm{~g}$ malt extract, $20 \mathrm{~g}$ glucose, and $1 \mathrm{~g}$ peptone purchased from Wako Pure Chemical Industries, Japan. After 7 days incubation, $1 \mathrm{~mL}$ of RBBR was pipetted to the culture to form final concentration of $100 \mathrm{mg} / \mathrm{L}$. Uninoculated flask served as a control. The decolorization efficiency and laccase activity were determined at $0,24,48,72$, and $96 \mathrm{~h}$ after the addition of the dye. Another synthetic dye (AB129, AO7, and RB5) were also tested as substitution of the RBBR. The experiments were carried out in triplicate and the reported results are shown as averages with standard deviation.

The measurement of dye decolorization was observed by using UV-Vis spectrophotometer (UV1800 Shimadzu, Japan) at the $\lambda_{\max }$ of each dye (Table 1). The percentage of decolorization was calculated by Eq. (1). Where Ai stands for initial absorbance and Af stands for final absorbance.

Decolorization $(\%)=($ Ai-Af $) / \mathrm{Ai} \times 100$ 
Table 1. Maximum wavelenght $\left(\lambda_{\max }\right)$ of synthetic dyes

\begin{tabular}{llll}
\hline Name of dye & Chemical structure & Functional group & $\lambda_{\max }(\mathrm{nm})$ \\
\hline Remazol Brilliant Blue R (RBBR) & & Anthraquinone & 592.5 \\
& & & \\
& & &
\end{tabular}

Acid Blue 129 (AB129)

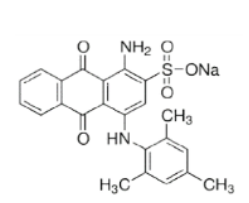

Anthraquinone

629

Acid Orange 7 (AO7)

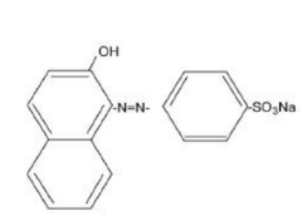

Monoazo

487

Reactive Black 5 (RB5)

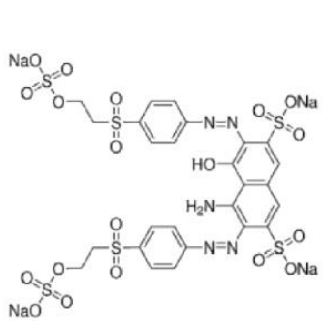

Diazo

598

\section{Laccase assay}

Laccase assay was performed by monitoring oxidation of ABTS (2,2'-azino-bis [3ethylbenzhiazoline]-6-sulfonic acid) at $420 \mathrm{~nm}$ with a $\mathrm{UV}-\mathrm{Vis}$ spectrophotometer. The reaction mixture consisted of $500 \mu \mathrm{L}$ ABTS $2 \mathrm{mM}, 400 \mu \mathrm{L}$ sodium

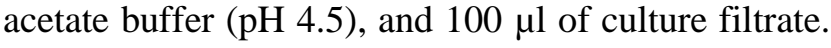
The molar extinction coefficient of ABTS at $420 \mathrm{~nm}$ was $\varepsilon_{420}=36,000 \mathrm{M}^{-1} \mathrm{~cm}^{-1}$ at $25^{\circ} \mathrm{C}$. One unit of laccase activity (U) was represented as the total of laccase which oxidized $1 \mu \mathrm{mol}$ of ABTS in one minute (Bagewadi et. al., 2017). Enzyme activity (U/L) was calculated according to Eq. (2) (Yanto et al., 2019).

Enzyme activity $=(\mathrm{Abs} / \varepsilon) \times\left(\mathrm{V}_{\text {mixture }} \mu \mathrm{L}: 10^{6}\right) \times 10^{6} \mathrm{x}$ $(60 / \mathrm{t}):\left(\mathrm{V}_{\text {enzyme }} \mu \mathrm{L}: 10^{3}\right)$

\section{RESULTS AND DISCUSSION}

\section{Dyes decolorization in agar medium}

Decolorization of RBBR and AB129 dyes in twolayered agar media containing lignin in bottom layer and dyes in top layer were preliminary evaluated to screen the dye degradation activity of the fungal strains. Addition of lignin in cultivation media can increase mycelium biomass and laccase activity in Basidiomycota (Matjuškova et al., 2017). Fungal growth and dye decolorization were assessed during the screening. Growth of the fungal strains was measured by development of mycelial diameter, while decolorization activity was examined by the formation of clear zone or disappearance of color from the media during $96 \mathrm{~h}$ incubation.

Among the screened fungal strains, isolate M3, H18, and GP1 showed promising result in dye decolorization. The result in Figure 1 shows that isolate $\mathrm{H} 18(2.77 \mathrm{~cm})$ was the fastest growing, followed by M3 $(2.70 \mathrm{~cm})$, and GP1 $(0.63 \mathrm{~cm})$. On the other hand, color removal of RBBR was observed larger in M3 $(3.33 \mathrm{~cm})$, followed by $\mathrm{H} 18(3.07 \mathrm{~cm})$, and GP1 $(1.30 \mathrm{~cm})$ (Figure 1.a.). Strain H18, with mycelium diameter of $2.90 \mathrm{~cm}$, exhibited the largest AB129 decolorization zone $(4.00 \mathrm{~cm})$, followed by M3 $(3.13 \mathrm{~cm})$, and GP1 $(1.17 \mathrm{~cm})$, which had mycelium diameter of $2.80 \mathrm{~cm}$, and $0.77 \mathrm{~cm}$, respectively (Figure 1.b). 

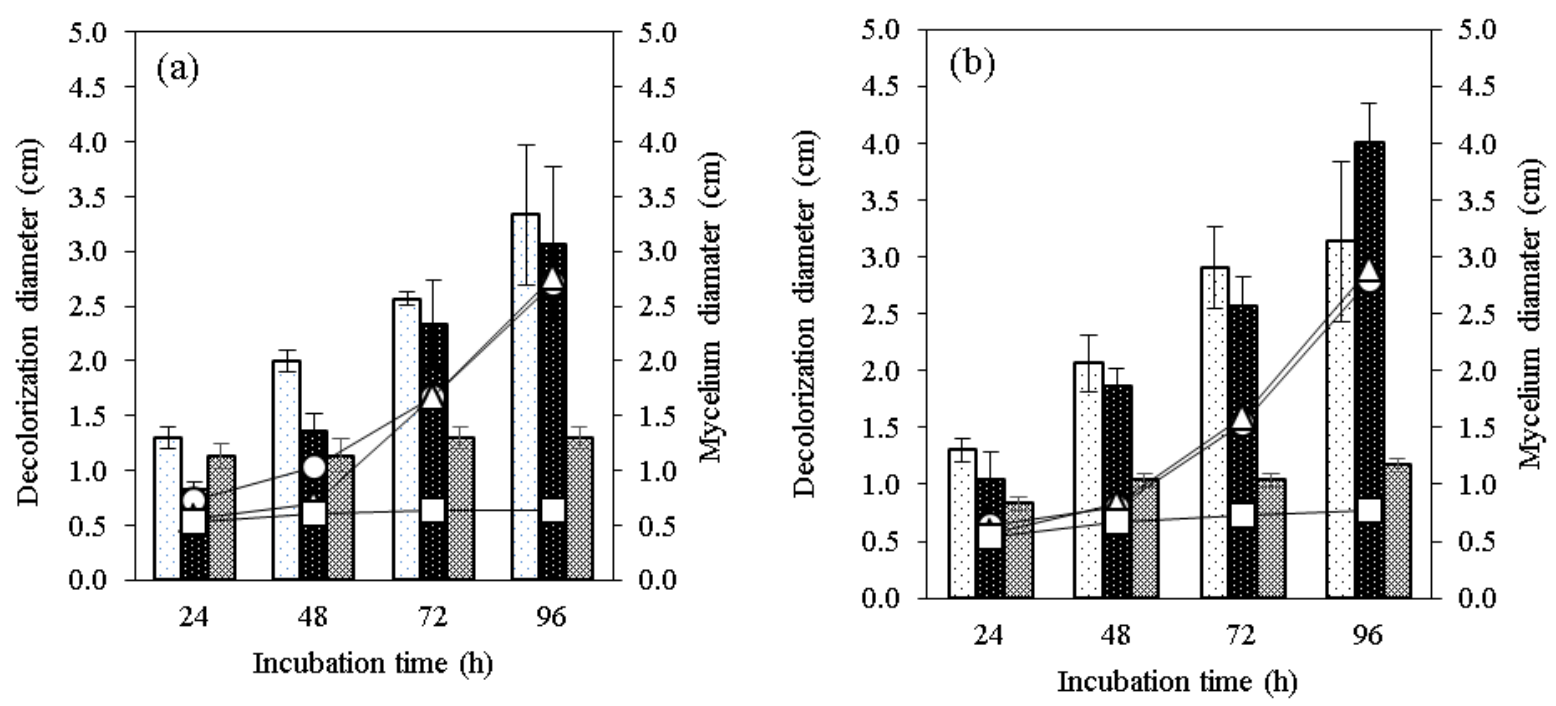

Figure 1. Growth of fungal strains mycelia and decolorization of (a) RBBR and (b) AB129 during $96 \mathrm{~h}$ incubation. Mycelium diameter M3 ( O), H18 ( $\triangle$, and GP1 ( $\square$, Decolorization by M3 ( $\square$ ), H18 ( $\square$ ), and GP1 (

Based on the results, it shows that the growth rate of most isolates was along with the decolorization rate. Hefnawy et. al. (2017) reported that decolorization ability of the fungi may have a positive correlation with the growth rate. These results also in accordance with the results obtained by Kaur et. al., 2015, that showed the correlation between the growth rate of the fungus Cordyceps militaris and its decolorization activity. The decolorization of dyes were occurred due to the extracellular enzymes that secreted by fungi into medium, since no chromophoric material being absorb into mycelium (Moreira-Neto et al., 2013). The production of extracellular enzyme, laccase, was associated with fungal growth in the medium. However, the laccase production depends on species of white-rot fungi used (Risdianto et. al., 2012). The white-rot fungi strains were producing and secreting ligninolytic enzymes variously in quantity to the surrounding, which play a role in dye decolorization (Strong \& Claus, 2011).

\section{Molecular identification analysis}

Molecular identification with NCBI BLAST was performed. Phylogenetic tree was constructed to confirm relationship of ITS rDNA region sequence from the fungal isolates with the closest strains from NCBI database by using maximum likelihood method. All sequences with the closest relationship to the analyzed isolates were obtained from GenBank to verify the phylogeny of these white-rot fungi. The phylogenetic tree is exhibited in Figure 2.

Isolate M3 is exhibited to be in one clade to Trametes sanguinea voucher CR35 and PRSC95 with 96\% bootstrap value. T. sanguinea has bright orange to red fruiting body and was commonly found grows on dead hard woods during summer and beginning of autumn. T. sanguinea has been reported to remove the color of phenolic dyes with decolorization efficiency above $60 \%$ after $24 \mathrm{~h}$ incubation (Ling et al., 2015).

The maximum likelihood tree of isolate $\mathrm{H} 18$ is clustered in the same position with Trametes polyzona strain WR710-1, isolate LM1020, and isolate PBURU K12 with $100 \%$ bootstrap value. This data indicates that, the new isolate $\mathrm{H} 18$ belongs to $T$. polyzona. White-rot fungi $T$. polyzona well known as a hard wood decomposer in the forest ecosystem (Chairin et al., 2013). It was reported that $T$. polyzona has a high potential in decolorizing of anthraquinone and azo dyes. (Lueangjaroenkit et. al., 2018).

On the other hand, strain GP1 is nested in one clade to species Neofomitella guangxiensis with $96 \%$ bootstrap value. It suggested that sequences of isolate GP1 is high similarity to $N$. guangxiensis. Species Neofomitella guangxiensis was firstly found in southern China in 2019 (Ji et al., 2019) and only three species of Neofomitella have been reported (Cui et al., 2019). However, to our knowledge, this is the first report that $N$. guangxiensis has ability to decolorize synthetic dyes. 


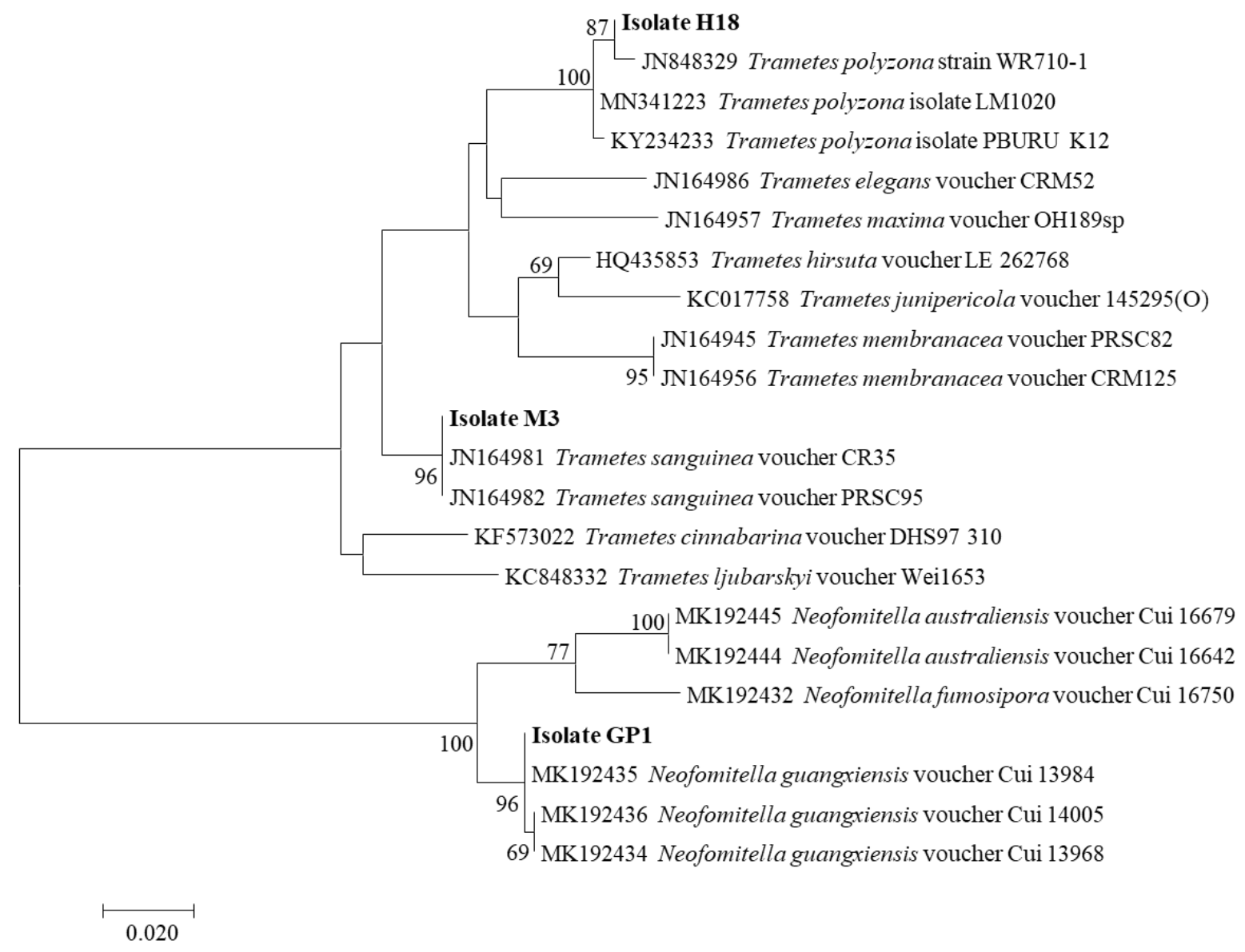

Figure 2. Phylogenetic tree for isolate H18, M3, and GP1, and related species based on ITS rDNA sequence. Bootstrap value $>40 \%$ are indicated at the nodes (1000 replication). The scale bar represents an evolutionary distance of 0.020

\section{Dyes decolorization in liquid medium}

Decolorization of four dyes in liquid medium after $96 \mathrm{~h}$ incubation is shown in Figure 3. The three fungal isolates were observed performing different decolorization activities. White-rot fungi $T$. sanguinea M3 exhibited $62.9 \%$ decolorization of RBBR and 59.9\% AB129, while $81.4 \%$ of RB5. Unfortunately, it has naturally orangish mycelium color which was the same color of $\mathrm{AO} 7$ and resulting of error in absorbance measurement. Fungi $N$. guangxiensis GP1 decolorized $76.3 \%$ of AB129 and $57.3 \%$ of RB5, and $22.6 \%$ of RBBR and $20.1 \%$ of AO7.
Whereas T. polyzona $\mathrm{H} 18$ showed impressive decolorization rate against anthraquinone and azo dyes. Strain $\mathrm{H} 18$ exhibited $95.4 \%$ of RBBR, $89 \%$ of $\mathrm{AB} 129$, and $94.8 \%$ of RB5 while $77.7 \%$ of AO7 degradation $96 \mathrm{~h}$ after addition of dyes into the culture. Figure 4 exhibits decolorization results by strain H18 towards the dyes after 96 hours incubation. Isolate $\mathrm{H} 18$ was visually observed degrading the thick color of RBBR, AB129, AO7, and RB5 become light transparent yellow which almost the same color of MGP broth. 

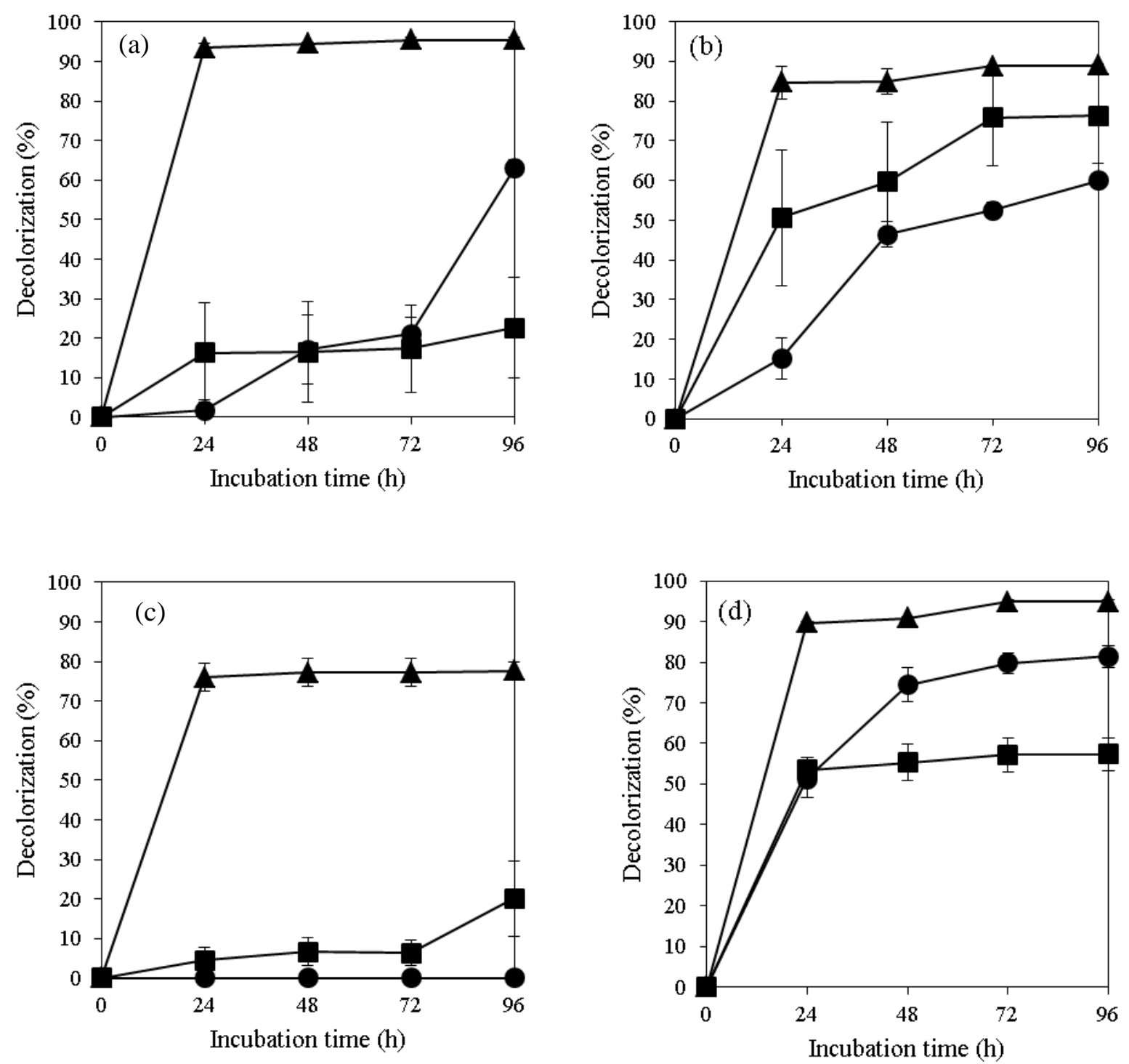

Figure 3. Decolorization of anthraquinone dyes: (a) RBBR and (b) AB129 and azo dyes: (c) AO7 and (d) RB5 decolorization activity by isolate M3 ( $)$, H18 ( $\mathbf{\Delta})$, and GP1 ( $\boldsymbol{\square})$ in liquid media
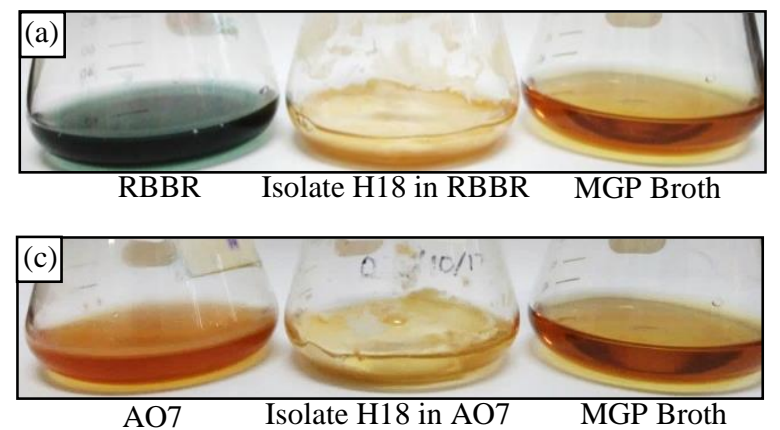
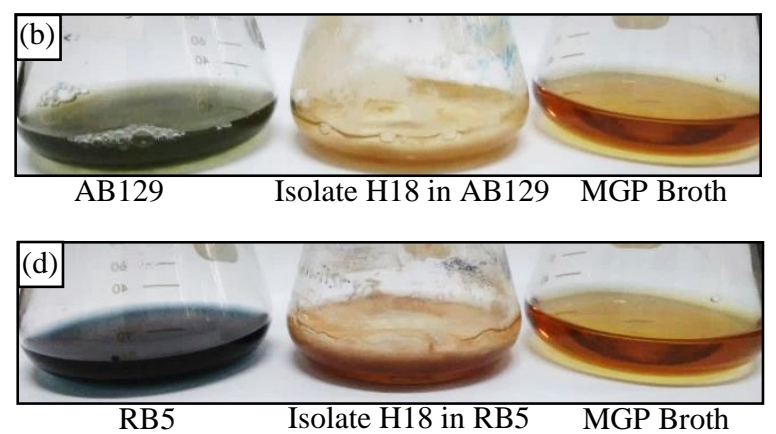

Figure 4. Decolorization of anthraquinone dyes after 96 hours incubation: (a) RBBR and (b) AB129 and azo dyes: (c) AO7 and (d) RB5 by isolate $\mathrm{H} 18$ 
The results showed that rapid decolorization was occurred in AB129 dye, while the most difficult to decolorized was AO7. It was reported that the diverse structure of dyes influence the different decolorization ability by the fungi (Sing et. al., 2017). In this case, AO7 dye has more complex structure than that of AB129 dye. This results also in line with the result from Yanto et. al. (2019) that reported azo dyes were more difficult to degradation than that of anthraquinone dyes.

\section{Laccase activity}

Laccase activity was evaluated during $96 \mathrm{~h}$ incubation of dyes decolorization by the three fungal

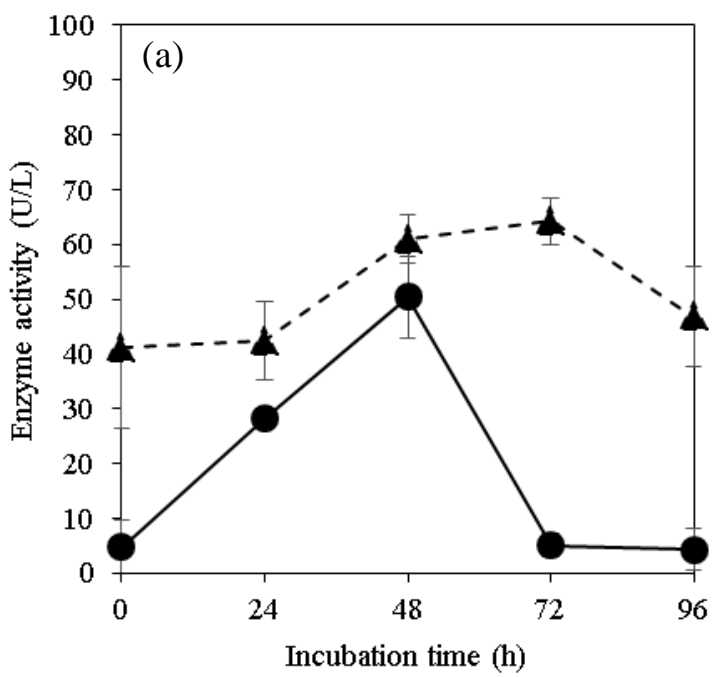

isolates and evaluated every $24 \mathrm{~h}$. The results of laccase activity assay for anthraquinone dyes (RBBR and AB129) and azo dyes (AO7 and RB5) decolorization are shown in Figure 5 and Figure 6, respectively.

The activities of the laccase were detectable after $24 \mathrm{~h}$ of incubation. Each fungal strain reached the maximum value on the different incubation time. Strain M3 showed the peak of laccase activity 0.0642 $\mathrm{U} / \mathrm{mL}$ in $\mathrm{AB} 129$ after $72 \mathrm{~h}$ incubation. Strain H18 evaluated to have the peak of $0.0924 \mathrm{U} / \mathrm{mL}$ in $\mathrm{AB} 129$ after $96 \mathrm{~h}$ incubation. Strain GP1 exhibited maximum laccase activity $0.0701 \mathrm{U} / \mathrm{mL}$ in AB129 after $24 \mathrm{~h}$ of incubation.

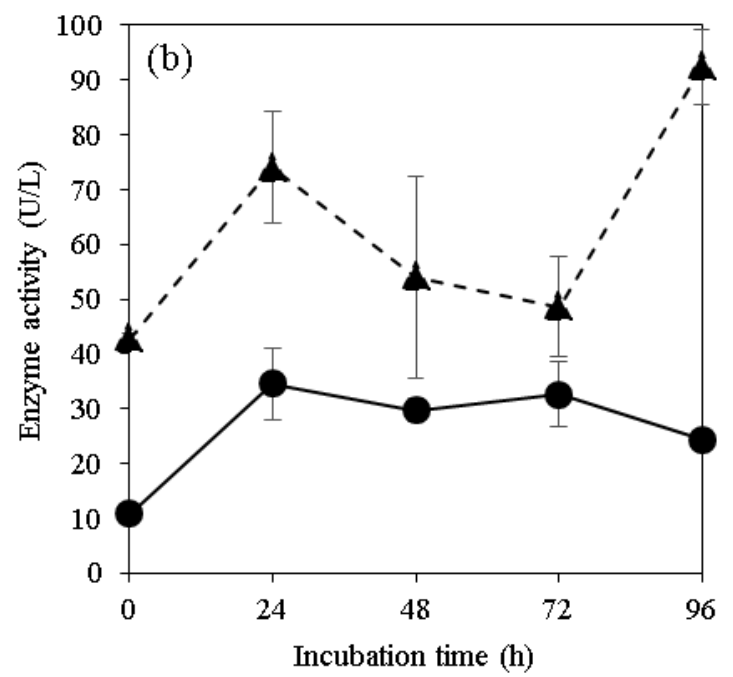

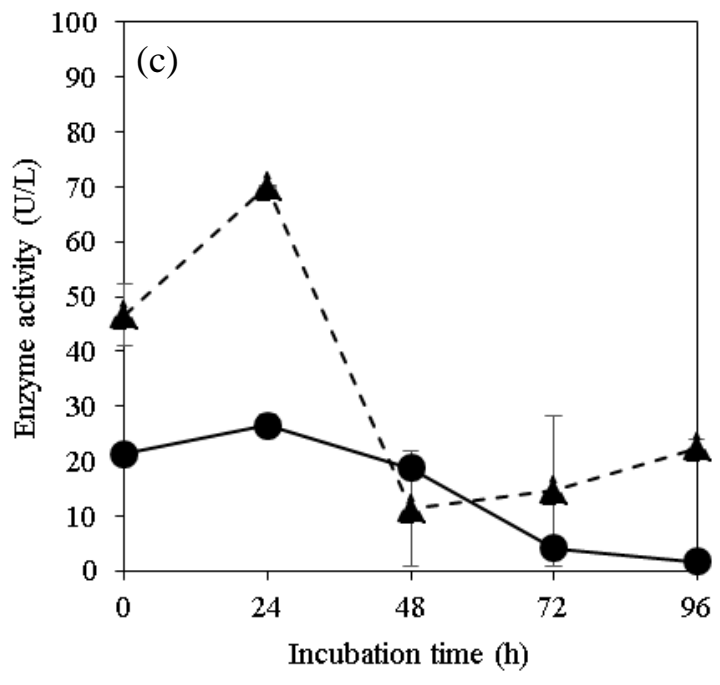

Figure 5. Laccase activity from (a) isolate M3, (b) isolate H18, (c) isolate GP1 during decolorization of RBBR (O) and AB129

Basidiomycetes ligninolytic enzymes, such as laccase, were reported to be either constitutive or inducible enzymes (Strong \& Claus, 2011). Laccase production was influenced by existence of phenolic compounds which related to lignin or lignin derivatives. Improvement of enzyme production was reported occurred in the presence of that compounds (Manavalan et. al, 2013). The presence of different structure of synthetic dyes could affect the laccase production by the strain M3, H18, and GP1. 
However, laccase activities were monitored to be decreased at the end of incubation. This phenomenon may occurred due to depletion of the substrate, $\mathrm{pH}$

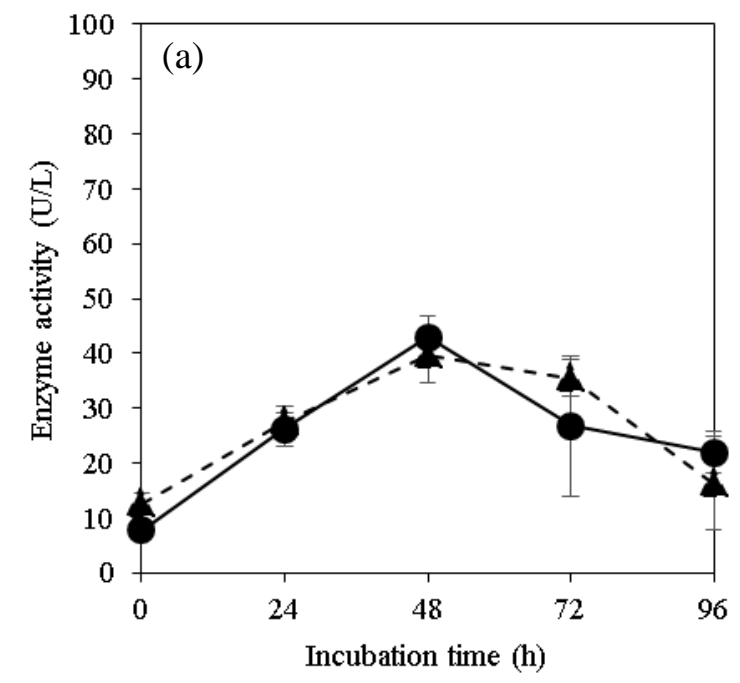

swing during reaction, or product accumulation that lead to inhibit the enzyme (Robinson, 2015).

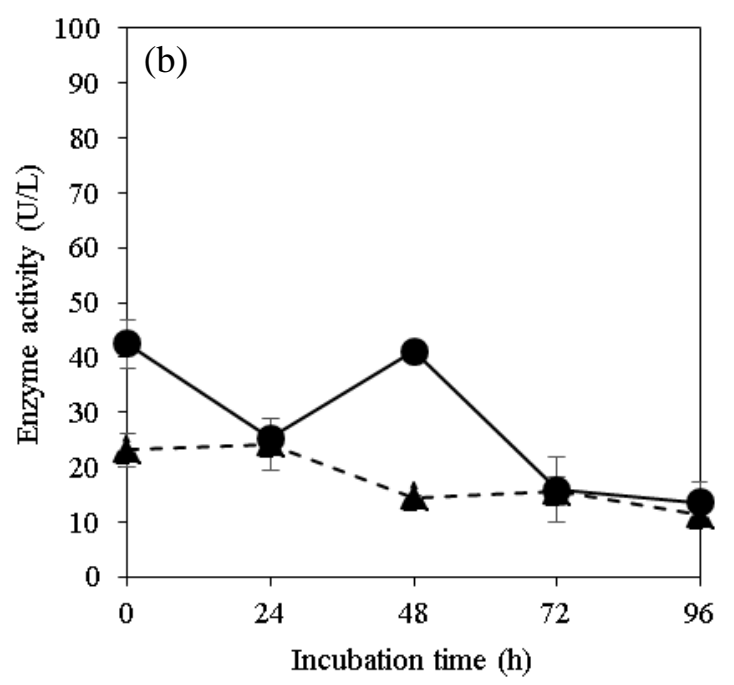

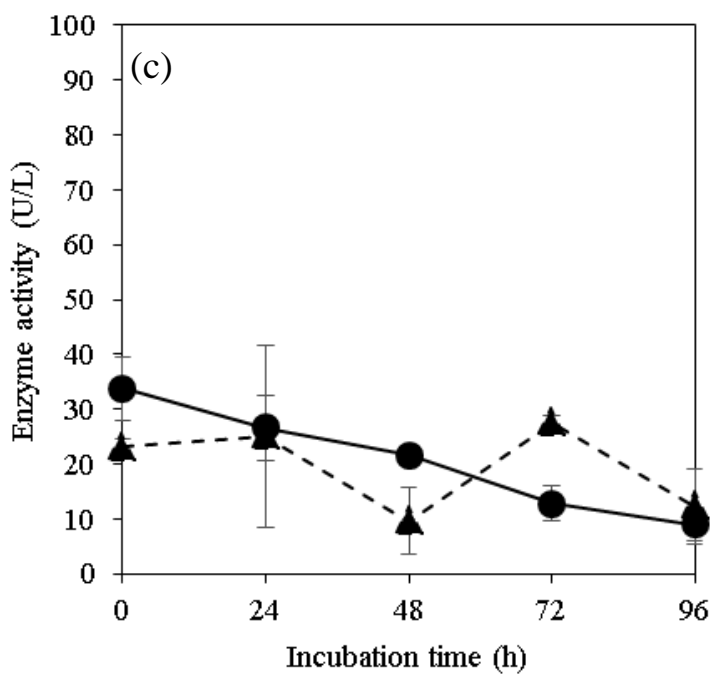

Figure 6. Laccase activity from isolate M3 (a), isolate H18 (b), and isolate GP1 (c) during decolorization of AO7 and RB5 (

To our knowledge, this is the first report on isolation, characterization and utilization of new isolates $T$. sanguinea $\mathrm{M} 3, T$. polyzona $\mathrm{H} 18$, and $N$. guangxiensis GP1 from Indonesia to decolorize anthraquinone and azo dyes. The results of this study provide a new potency of Indonesian WRF isolated from Batam and Kuningan Botanical Garden as bioremediation agents of synthetic dyes contaminated water. Since many contaminations of water bodies, such as river in Indonesia are recently high, this study may be used as a bioremediation strategy to reduce the toxic dyes.

\section{CONCLUSIONS}

Newly isolated fungi $T$. sanguinea (M3), $T$. polyzona (H18), and $N$. guangxiensis (GP1) exhibited decolorization activities against anthraquinone (RBBR and A129) and azo (AO7 and R5B) dyes. T. polyzona showed the highest decolorization activity which capable of decolorizing more than $90 \%$ of RBBR, AB129, and RB5 while over than $70 \%$ of AO7 after $96 \mathrm{~h}$ incubation. During the decolorization of dyes, fungal laccases reached the maximum value at different incubation time for each dye, then decreased at the end of incubation. The study suggests that strain $\mathrm{H} 18$ has the potential to be used 
in bioremediation of textile wastewater in environment.

\section{ACKNOWLEDGEMENT}

The authors acknowledge the facilities, the scientific and technical assistance of the Integrated Laboratory of Bioproducts (iLaB) at the Indonesian Institute of Science (LIPI). This research was supported by LIPI through KRD Program 2017 and IBSAP (Indonesian Biodiversity Strategy and Action Plan) project 2018-2019.

\section{REFERENCES}

Antošová, Z., Herkommerová, K., Pichová, I., \& Sychrová, H. (2018). Efficient secretion of three fungal laccases from Saccharomyces cerevisiae and their potential for decolorization of textile industry effluent-A comparative study. Biotechnology Progress, 34(1), 69-80.

Bagewadi, Z. K., Mulla, S. I., \& Ninnekar, H. Z. (2017). Purification and immobilization of laccase from Trichoderma harzianum strain HZN10 and its application in dye decolorization. Journal of Genetic Engineering and Biotechnology, 15(1), 139-150.

Bibi, I., Javed, S., Ata, S., Majid, F., Kamal, S., Sultan, M., Jalani, K., Umair, M., Khan, M.I., Iqbal, M. (2019). Biodegradation of synthetic orange G dye by Plearotus sojar-caju with Punica granatum peal as natural mediator. Biocatalysis and Agricultural Biotechnology, 22, 101420.

Cao, X., Wang, H., Zhang, S., Nishimura, O., \& Li, X. (2018). Azo dye degradation pathway and bacterial community structure in biofilm electrode reactors. Chemosphere, 208, 219-225.

Chairin, T., Nitheranont, T., Watanabe, A., Asada, Y., Khanongnuch, C., \& Lumyong, S. (2013). Biodegradation of bisphenol A and decolorization of synthetic dyes by laccase from white-rot fungus, Trametes polyzona. Applied Biochemistry and Biotechnology, 169(2), 539-545.

Cui, B. K., Li, H. J., Ji, X., Zhou, J. L., Song, J., Si, J., Yang, Z.L., Dai, Y. C. (2019). Species diversity, taxonomy and phylogeny of Polyporaceae (Basidiomycota) in China. Fungal Diversity, 97, 137-392.

Hefnawy, M. A., Gharieb, M. M., Shaaban, M. T., \& Soliman, A. M. (2017). Optimization of culture condition for enhanced decolorization of Direct blue dye by Aspergillus flavus and Penicillium canescens. Journal of Applied Pharmaceutical Science, 7(2), 083-092.

Ji, X., Wu, D. M., Song, C. G., Liu, S., Si, J., \& Cui, B. K. (2019). Two new Neofomitella species
(Polyporaceae, Basidiomycota) based on morphological and molecular evidence. Mycological Progress, 18(4), 593-602.

Kant, R. (2012). Textile dyeing industry an environmental hazard. Natural Science, 4(01), 2226.

Kaur, B., Kumar, B., Garg, N., \& Kaur, N. (2015). Statistical optimization of conditions for decolorization of synthetic dyes by Cordyceps militaris MTCC 3936 using RSM. BioMed Research International, 2015, 1-17.

Lavanya, C., Dhankar, R., Chhikara, S., Sheoran, S. (2016). Degradation of toxic dyes- A review. International Journal of Pure \& Applied Bioscience, 4(5), 81-89.

Levin, L., Melignani, E., \& Ramos, A. M. (2010). Effect of nitrogen sources and vitamins on ligninolytic enzyme production by some white-rot fungi. Dye decolorization by selected culture filtrates. Bioresource Technology, 101(12), 45544563.

Li, H. hong, Wang, Y. tao, Wang, Y., Wang, H. xia, Sun, K. kai, \& Lu, Z. mei. (2019). Bacterial degradation of anthraquinone dyes. Journal of Zhejiang University: Science B, 20(6), 528-540.

Ling, Z. R., Wang, S. S., Zhu, M. J., Ning, Y. J., Wang, S. N., Li, B., Yang, A.Z., Zhang, G.Q., Zhao, X. M. (2015). An extracellular laccase with potent dye decolorizing ability from white-rot fungus Trametes $\mathrm{sp}$. LAC-01. International Journal of Biological Macromolecules, 81, 785793.

Lueangjaroenkit, P., Teerapatsakul, C., \& Chitradon, L. (2018). Morphological characteristic regulation of ligninolytic enzyme produced by Trametes polyzona. Mycobiology, 46(4), 396-406.

Madhushika, H. G., Ariyadasa, T. U., \& Gunawardena, S. H. P. (2020). Biological decolourization of textile industry wastewater by a developed bacterial consortium. Water Science and Technology, 80(10), 1910-1918.

Manavalan, T., Manavalan, A., Thangavelu, K. P., \& Heese, K. (2013). Characterization of optimized production, purification and application of laccase from Ganoderma lucidum. Biochemical Engineering Journal, 70, 106-114.

Matjuškova, N., Okmane, L., Zala, D., Rozenfelde, L., Puke, M., Kruma, I., Vedernikovs, N., Rapoport, A. (2017). Effect of lignin-containing media on growth of medicinal mushroom lentinula edodes. Proceedings of the Latvian Academy of Sciences, Section B: Natural, Exact, and Applied Sciences, 71(1), 38-42.

Moreira-Neto, S. L., Mussatto, S. I., Machado, K. M. G., \& Milagres, A. M. F. (2013). Decolorization of salt-alkaline effluent with industrial reactive 
dyes by laccase-producing basidiomycetes strains. Letters in Applied Microbiology, 56(4), 283-290.

Padmapriya, G., Manikandan, A., Krishnasamy, V., Jaganathan, S. K., \& Antony, S. A. (2016). Spinel NixZn1-xFe2O4 $(0.0 \leq x \leq 1.0)$ nanophotocatalysts: Synthesis, characterization and photocatalytic degradation of methylene blue dye. Journal of Molecular Structure, 1119, 39-47.

Patel, H., Gupte, S., Gahlout, M., \& Gupte, A. (2014). Purification and characterization of an extracellular laccase from solid-state culture of Pleurotus ostreatus HP-1. 3 Biotech, 4(1), 77-84.

Risdianto, H., Sofianti, E., Suhardi, S. H., \& Setiadi, T. (2012). Optimisation of laccase production using white-rot fungi and agriculture wastes in solid state fermentation. ITB Journal of Engineering Science, 44 B(2), 93-105.

Robinson, P. K. (2015). Enzymes: principles and biotechnological applications. Essays in Biochemistry, 59, 1-41.

Šekuljica, N. Ž., Prlainović, N. Ž., Stefanović, A. B., Žuža, M. G., Čičkarić, D. Z., Mijin, D. Ž., \& Knežević-Jugović, Z. D. (2015). Decolorization of anthraquinonic dyes from textile effluent using horseradish peroxidase: Optimization and kinetic study. The Scientific World Journal, 2015, 1-12.

Sing, N. N., Husaini, A., Zulkharnain, A., \& Roslan, H. A. (2017). Decolourisation capabilities of ligninolytic enzymes produced by Marasmius cladophyllus UMAS MS8 on Remazol Brilliant Blue R and other azo dyes. BioMed Research International, 2017, 1-8.

Solís, M., Solís, A., Pérez, H. I., Manjarrez, N., \& Flores, M. (2012). Microbial decolouration of azo dyes: A review. Process Biochemistry, 47(12), 1723-1748.

Strong, P. J., \& Claus, H. (2011). Laccase: A review of its past and its future in bioremediation. Critical Reviews in Environmental Science and Technology, 41(4), 373-434.

Yanto, D. H. Y., Auliana, N., Anita, S. H., \& Watanabe, T. (2019). Decolorization of synthetic textile dyes by laccase from newly isolated Trametes hirsuta EDN084 mediated by violuric acid. IOP Conference Series: Earth and Environmental Science, 374(1), 012005. 